of the building, but that even if they had, the necessity shown would have outweighed the adverse effect. ${ }^{3}$ [WA]

doi:10.1017/So956618X1000102X

\title{
Hashwani v Jivraj
}

Court of Appeal: More-Bick, Aikens and Buxton LJJ, June 2010 Arbitration - Equality (Religion and Belief) (Amendment) Regulations 2003

The court heard an appeal against the judgment of David Steel J sitting in the Commercial Court (noted at (2010) 12 Ecc LJ 121). The parties had been business associates who had agreed that if arbitration in the case of the winding up of their joint venture were to take place that the arbitrator appointed must be a member of the Ismaili Muslim community. One party had appointed an arbitrator from outside that community. The Commercial Court had held that the Equality (Religion and Belief) (Amendment) Regulations 2003 did not apply as an arbitrator was not an employee as covered by the regulations and thus that the appointment of an arbitrator from outside the community was void. The Court of Appeal upheld the appeal in part. The 2003 Regulations did apply to the appointment of arbitrators and being a member of this particular community was not a genuine occupational requirement under the regulations for carrying out the task. However, the striking out of the requirement for any arbitrator to be an Ismaili Muslim was held to invalidate the whole of the pertinent clause of the parties' agreement. Thus the ruling that the appointment of the arbitrator in question was void was upheld. [WA]

doi:10.1017/So956618X10001031

\section{Re St Andrew, Sedbergh \\ Bradford Consistory Court: Walford Ch, July 2010 \\ Cross - aesthetics - doctrinal objections}

The petitioners sought a faculty to hang an ebony and ivory cross above the pulpit. Seventeen of the twenty-two PCC members present had voted in favour of the proposal and four against. The DAC supported the petition. One of the PCC members who had voted against the proposal objected to the grant of a faculty on doctrinal and aesthetic grounds. No other objections had 